\title{
PEG STYLE OF INVESTING : AN ANALYSIS
}

\author{
${ }^{1}$ Dr. B.M. Kanahalli \\ ${ }^{2}$ Sachin Balbhimrao
}

\section{Section : I}

\section{Introduction}

In our daily life, when we want to buy Television set, Motor Car or any other durable product, we look at the quality, long life, brand name and fair price. Likewise, while investing in Equities most of the investors ignored this basic principle of investments. This is evident from the volatility of the Indian Equity market during the past several years which witnessed high speculation, lack of direction and overall confusion that lead to fluctuations in the Indian stock market index beyond the justifiable levels.

The ultimate of investing in equity is to get healthy return by holding the stock for longer duration. The return on a stock (dividend and capital appreciation) is tied to the future performance of the company. Further, an investor should also know why he is buying or selling a particular stock and the timing of his buy-sell decisions.

Moreover investors who are directly investing in the stock market should have the knowledge and skill of stock valuation i.e. whether a particular stock is overvalued, undervalued or fairly valued. Investors must bear in mind that the true value of stock is first of all a quality company and secondly it is the selling price that you can be confident of future appreciation which yields healthy returns. So it is better to think some stock picking strategies which is treated as art rather than science. For that he should identify good companies in terms of good performance, strong and consistent growth and optimum debt-equity level. ${ }^{1}$
Hence this study identifies PEG ratio as stock picking strategy for retail investing class as it is one of the better valuation measures to identify the undervalued stocks in the Indian Equity market.

\section{Section : II}

\section{Review of Literature}

Following are the major reviews which help in digging the research gap:

Nicholson (1968) extended his earlier work through earnings of 189 Companies between 1937 and 1962 . Where he divides the companies in to five groups by $\mathrm{P} / \mathrm{E}$ ratio, he found that the average return over seven years were $131 \%$ that is $12.71 \%$ per year for companies with P/E below ten.. He concludes that investors who invest in stocks seek the greater productivity which is represented in stocks with a low $\mathrm{P} / \mathrm{E}$ rather than high $\mathrm{P} / \mathrm{E}$ ratios. Basu(1975) in his paper the price performance of NYSE industrials between 1957 to 1971 at the start of each April, stocks were ranked by $\mathrm{P} / \mathrm{E}$ based on the previous financial years results and divided into quintiles. $\mathrm{He}$ found that the average return per annum with high $\mathrm{P} /$ E were $9.3 \%$ compare to $16.3 \%$ of low P/E and conclude that there was a relationship between investment return and quintile $\mathrm{P} / \mathrm{E}$ values. Fuller, Huberts and Levinson (1993) in their paper re-examined Ball's arguments who conducted the apparent existence of $P / E$ effects by including wide variety of possible explanatory factors for the out-performance of low P/E stocks.. They found that low P/E stocks yields higher returns from 1973-1990 but this model does not consider

1 Professor, Dean and Head of Department, Department of Commerce, Gulbarga University, Gulbarga.

2 Project fellow, Department of Commerce, Gulbarga University, Gulbarga. 
superior low P/E returns. In another study conducted by Dreman and Lufkin (1997) investigates the performance of value strategies in U.K. with 1500 largest companies within the industries from 1970 to 1995. They formed the portfolios based on the low $\mathrm{P} / \mathrm{E}, \mathrm{PCF}, \mathrm{P} / \mathrm{BV}$ and dividend yield all assign below and above market returns for holding periods ranging from one to five years. They found that the value strategies within the industries provide similar results to those based on the entire market. But low P/E returns were statistically insignificant to the market average. Sharma (1984) discussed the concept of $\mathrm{P} / \mathrm{E}$ ratios as a tool of fundamental analysis, he further stressed on the need for more work in this direction especially in India. Gillan(1990) examined the existence of P/E ratio and size effect in the New Zealand Stock Exchange, found that the size effect was documented and there were no traces of $P / E$ effect. Obaidullah (1991) investigated the existence of $P / E$ anomaly in the Indian stock market he found that the return on low $\mathrm{P} / \mathrm{E}$ portfolio was consistently higher than the return on high P/E portfolio. He concludes that stock price adjustment to earnings information in Indian stock market is purely biased and inaccurate.Campbell and Shiller (1988) and Shiller (2000) in his study entitled 'Irrational Exuberance of $\mathrm{P} / \mathrm{E}$ ' investigate value of multi-year earnings averages. However they also looked at earnings over the index as a whole, rather than the earnings level of individual companies with special reference to the P/E effect. Tuli and Mittal (2001) focused on the factors influencing P/E ratios of Indian equities. The results reveal that the variation in the market price and dividend payout ratio affects the $\mathrm{P} / \mathrm{E}$ ratios across the industries. Mohanty (2002) in his study entitled 'Price-to-book value and Earnings-to-Price ratio' shows that size, market, leverage, P/B, Earnings to Price ratio were highly co related with stock returns. Particularly Earnings to Price ratio was found to be positively correlated with stock returns.

Mangala and Mittal (2005) found that the portfolio with negative or low P/E have outperformed against other portfolios formed on the basis of raw returns as risk adjusted returns. They conclude that seasonality or pattern in distribution in the stock exists in the
Indian stock market. Dhankar and Kumar (2007) examines P/E ratio of BSE 100 Companies over a period of 10 years. The paper found no consistent relationship between the portfolios expected return and their corresponding P/E ratios. It is also observed that the stock market fail to reflect instantaneous response pertaining to earnings information.

After reviewing the above studies we have been unable to find any exhaustive academic research in the area of Price Earning Growth Style (PEG) of investing in Indian Context which reveals the true value of stock. Hence this research gap is prompted us to take the study on 'PEG style of investing' in Indian Context.

\subsection{OBJECTIVES :}

The following objectives were set for our study.

1. To estimate the expected growth rate of earnings for the respective companies.

2. To know the relationship between price earnings ratio and expected growth rate of earnings in the form of PEG ratio.

3. To find out value stocks using the PEG ratio as a metric of investment.

4. To understand the performance of different portfolios consisting of undervalued, overvalued and fairly valued stocks.

5. To offer feasible suggestions in the light of findings to retail investing class.

\subsection{METHODOLOGY:}

In order to carry out our study, the following methodology is employed

Firstly, we have determined expected growth rate of earnings, ' $g$ ' using Return on Equity and Retained earnings ratio. In second, we have computed respective PEG ratio of all Sectors of our study dividing P/E ratio by Expected Growth rate. The portfolio of undervalued stocks and overvalued stocks has been formed separately using PEG as the metric of investment. PEG less than one is taken as undervalued stocks and more than one is taken as overvalued stocks. In constructing the portfolio of undervalued or overvalued stocks as the case may 
be, a capital of Rs. $1,00,000$ is allocated in 5 stocks each of Rs.20, 000. Finally return on investment is derived using the following equation.

$$
\mathrm{ROI}=\frac{\mathrm{VIC}-\mathrm{VIB}}{\mathrm{VIB}}
$$

Where,

$\mathrm{ROI}=$ Return on Investment

$\mathrm{VIC}=$ Value of Investment at Closing

$\mathrm{VIB}=$ Value of Investment at Beginning accordingly the analysis was carried out to bring findings and conclusion.

\subsection{SOURCES OF INFORMATION:}

For any study we require certain sources of information. There are two sources of information such as primary source and secondary source of information. For our study only secondary source of information is used. To speak specifically, our study covers 30 scripts representing 6 sectors of BSE and the period of study covers from 2005 to 2009.

\subsection{ORGANISATION OF THE STUDY :}

The present study is organized in 4 sections. The first section bring introduction to PEG investing, the second section is organized to present a review of literature, objectives, methodology and sources of information. Results and analysis was carried out in the third sections. Finally, Findings, Limitations and Suggestions were offered in final section.

\subsection{SCOPE OF THE STUDY:}

This study is expected to produce certain findings and evidences. The retail investing class in particular and other investing class in general would be guided to make the best return from Equity Investment.

SECTION: III

RESULTS AND ANALYSIS

Table: 3.1 Showing P/E, Growth and PEG of Select Automobile Stocks

\begin{tabular}{|c|l|l|c|c|}
\hline SI. No & Automobile Sector & P/E ratio & Growth rate (Percentage) & PEG \\
\hline 01 & Hero Honda & 17.6 & 19.5 & 0.9 \\
\hline 02 & T.V.S. Motor Co & 19.03 & 16.70 & 1.1 \\
\hline 03 & Ashok Layland & 14.37 & 9.95 & 1.4 \\
\hline 04 & Eicher motors Itd & 22.63 & 19.33 & 1.3 \\
\hline 05 & Tata motors Itd & 9.59 & 17.57 & 0.5 \\
\hline \multicolumn{5}{|l}{ Source: Capital Market database } \\
\hline
\end{tabular}

Table: 3.2 Showing P/E, Growth and PEG of Select Public Sector Bank Stocks

\begin{tabular}{|c|l|c|c|c|}
\hline SI. No & Public Sector Banks & P/E ratio & Growth rate (Percentage) & PEG \\
\hline 01 & State Bank of India & 7.63 & 14.99 & 0.5 \\
\hline 02 & Bank of India & 3.94 & 5.32 & 0.7 \\
\hline 03 & UCO Bank & 2.41 & 15.84 & 0.1 \\
\hline 04 & Corporation Bank & 2.99 & 9.04 & 0.3 \\
\hline 05 & Andhra Bank & 3.54 & 20.92 & 0.1 \\
\hline
\end{tabular}

Source: Capital Market database 


\begin{tabular}{|c|l|c|c|c|}
\hline \multicolumn{6}{|c|}{ Table: 3.3 Showing P/E, Growth and PEG of Select Cement Company Stocks } \\
\hline SI. No & Cement Sector & P/E ratio & Growth rate (Percentage) & PEG \\
\hline 01 & A.C.C. & 10.68 & 8.21 & 1.3 \\
\hline 02 & Shree Cement & 4.32 & 4.87 & 0.8 \\
\hline 03 & J K Cement & 2.01 & 11.53 & 0.1 \\
\hline 04 & Andhra Cement & 5.99 & 0.0 & 0.0 \\
\hline 05 & Ultra tech Cement & 7.1 & 22.51 & 0.3 \\
\hline Source: Capital Market database & & \\
\hline
\end{tabular}

\begin{tabular}{|c|l|l|c|c|}
\hline \multicolumn{6}{|c|}{ Table: 3.4 Showing P/E, Growth and PEG of Select Power Stocks } \\
\hline SI. No & Computer Software Sector & P/E ratio & Growth rate (Percentage) & PEG \\
\hline 01 & Tata Power Company & 19.03 & 5.09 & 3.7 \\
\hline 02 & Reliance Power & 98.56 & 849.4 & 0.1 \\
\hline 03 & NTPC & 19.29 & 7.95 & 2.4 \\
\hline 04 & NHPC & 0 & 3.58 & 0.0 \\
\hline 05 & JSW Energy & 0 & 6.46 & 0.0 \\
\hline Source: Capital Market database & \multicolumn{3}{|}{} \\
\hline
\end{tabular}

\begin{tabular}{|c|l|l|c|c|}
\hline \multicolumn{6}{|c|}{ Table: 3.5 Showing P/E, Growth and PEG of Select Pharmaceutical Stocks } \\
\hline SI. No & Pharmaceuticals Sector & P/E ratio & Growth rate (Percentage) & PEG \\
\hline 01 & Ankur Drugs Pharma Ltd. & 3.53 & 23.68 & 0.1 \\
\hline 02 & Cipla & 22.77 & 17.48 & 1.3 \\
\hline 03 & Ranbaxy & 38.05 & -23.11 & 0.0 \\
\hline 04 & Sun Pharma & 18.93 & 20.17 & 0.9 \\
\hline 05 & Glen mark Pharma & 18.29 & 19.94 & 0.9 \\
\hline Source: Capital Market database & & \\
\hline
\end{tabular}




\begin{tabular}{|l|l|l|c|c|}
\hline \multicolumn{6}{|l|}{ Table: 3.6 Showing P/E, Growth and PEG of Select Computer Software Stocks } \\
\hline SI. No & Computer SoftwareSector & P/E ratio & Growth rate (Percentage) & PEG \\
\hline 01 & HCL technologies Itd. & 13.56 & -11.04 & 0.0 \\
\hline 02 & Infosys technologies & 13.55 & 29.42 & 0.4 \\
\hline 03 & Rolta & 5.57 & 14.68 & 0.3 \\
\hline 04 & Religare Technova Global Solutions & 0.0 & 15.11 & 0.0 \\
\hline 05 & Wipro & 12.51 & 22.29 & 0.5 \\
\hline Source: Capital Market database & & \\
\hline
\end{tabular}

\begin{tabular}{|l|c|c|c|c|c|c|c|}
\hline \multicolumn{7}{|c|}{ 3.7 TABLE SHOWING PORTFOLIO PERFORMANCE OF UNDER VALUED STOCKS } \\
\hline $\begin{array}{c}\text { Company } \\
\text { Name }\end{array}$ & $\begin{array}{c}\text { Capital } \\
\text { Allocation }\end{array}$ & $\begin{array}{c}\text { Current } \\
\text { Market Price } \\
(31 / 3 / 05)\end{array}$ & $\begin{array}{c}\text { No. } \\
\text { of } \\
\text { shares }\end{array}$ & $\begin{array}{c}\text { Current } \\
\text { Market Price } \\
(31 / 3 / 09)\end{array}$ & $\begin{array}{c}\text { Investment } \\
\text { Value as on } \\
(31 / 3 / 05)\end{array}$ & $\begin{array}{c}\text { Investment } \\
\text { Value as on } \\
(31 / 3 / 09\end{array}$ & $\begin{array}{c}\text { Return On } \\
\text { Investment } \\
(\%)\end{array}$ \\
\hline $\begin{array}{l}\text { Tata motors } \\
\text { limited }\end{array}$ & 20,000 & 653.00 & 30 & 792.60 & 20,000 & 23,778 & 0.18 \\
\hline $\begin{array}{l}\text { State Bank } \\
\text { of India }\end{array}$ & 20,000 & 907.45 & 22 & $2,269.45$ & 20,000 & 49,928 & 1.49 \\
\hline $\begin{array}{l}\text { Bank of } \\
\text { India }\end{array}$ & 20,000 & 127.55 & 156 & 385.00 & 20,000 & 60,060 & 2.00 \\
\hline UCO Bank & 20,000 & 25.20 & 793 & 55.75 & 20,000 & 44,210 & 1.21 \\
\hline Shree Cement & 20,000 & 489.50 & 40 & $1,926.10$ & 20,000 & 77,044 & 2.85 \\
\hline Total & & & & & $1,00,000$ & $\mathbf{2 , 5 5 , 0 2 0}$ & \\
\hline Average & & & & & & & 1.54 \\
\hline
\end{tabular}

\section{PERFORMANCE OF UNDER VALUED STOCKS}

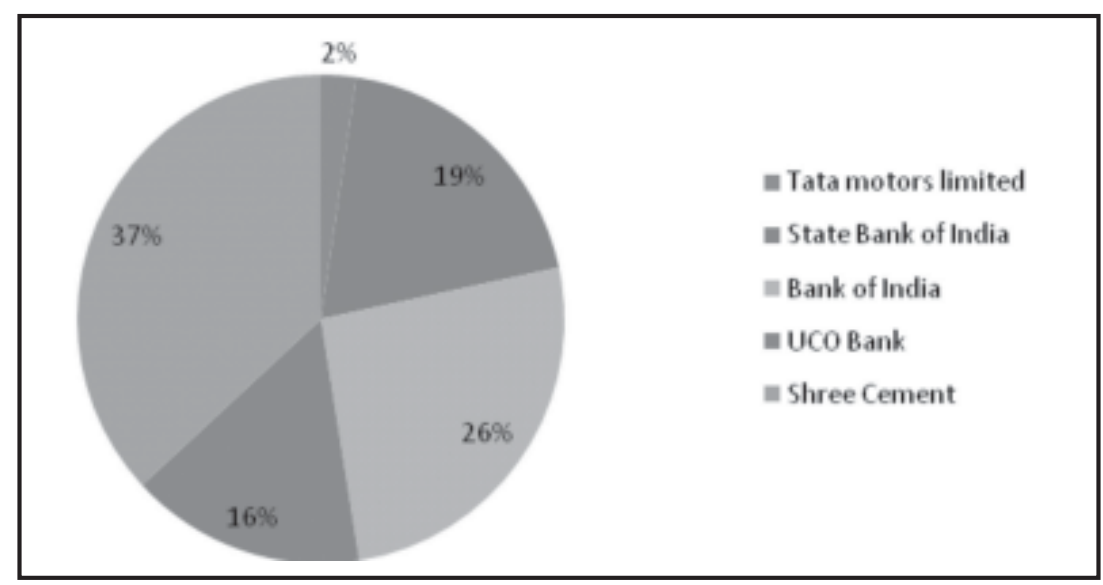




\begin{tabular}{|l|c|c|c|c|c|c|c|}
\hline \multicolumn{7}{|c|}{3.8 TABLE SHOWING PORTFOLIO PERFORMANCE OF OVER VALUED STOCKS } \\
\hline $\begin{array}{l}\text { Company } \\
\text { Name }\end{array}$ & $\begin{array}{c}\text { Capital } \\
\text { Allocation }\end{array}$ & $\begin{array}{c}\text { Current } \\
\text { Market Price } \\
(31 / 3 / 05)\end{array}$ & $\begin{array}{c}\text { No. } \\
\text { of } \\
\text { shares }\end{array}$ & $\begin{array}{c}\text { Current } \\
\text { Market Price } \\
(31 / 3 / 09)\end{array}$ & $\begin{array}{c}\text { Investment } \\
\text { Value as on } \\
(31 / 3 / 05)\end{array}$ & $\begin{array}{c}\text { Investment } \\
\text { Value as on } \\
(31 / 3 / 09\end{array}$ & $\begin{array}{c}\text { Return On } \\
\text { Investment } \\
(\%)\end{array}$ \\
\hline $\begin{array}{l}\text { Ashok } \\
\text { Layland }\end{array}$ & 20,000 & 31.85 & 628 & 49.55 & 20,000 & 31,117 & 0.55 \\
\hline $\begin{array}{l}\text { Eicher } \\
\text { motors }\end{array}$ & 20,000 & 229.95 & 86 & 655.25 & 20,000 & 56,352 & 1.81 \\
\hline Cipla & 20,000 & 443.40 & 45 & 335.60 & 20,000 & 15,102 & -0.24 \\
\hline N.T.P.C. & 20,000 & 112.10 & 178 & 235.70 & 20,000 & 41,955 & 1.09 \\
\hline A.C.C & 20,000 & 534.20 & 37 & 871.50 & 20,000 & 32,246 & 0.61 \\
\hline Total & & & & & $1,00,000$ & $\mathbf{1 , 7 6 , 7 7 2}$ & \\
\hline Average & & & & & & & $\mathbf{0 . 7 6}$ \\
\hline
\end{tabular}

PERFORMANCE OF OVER VALUED STOCKS

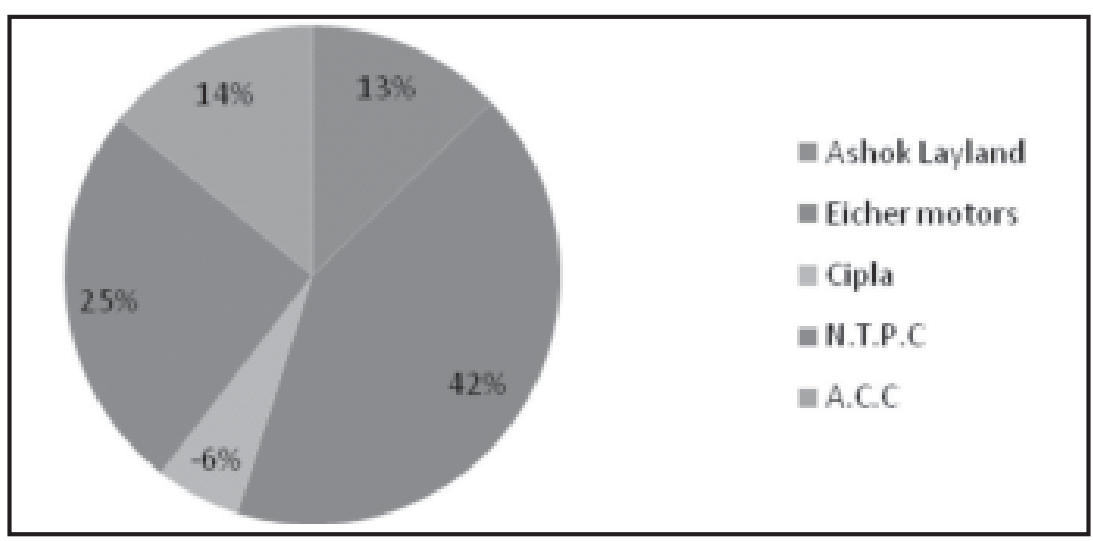

The total numbers of scripts selected for our study were 30 representing 6 Sectors of Indian Equity market. Out of these the best performing companies on the basis of PEG as a metric of investment were Tata motors from Automobile Industry with 18\% return on investment, State Bank of India with $149 \%$, Bank of India with $200 \%$ and UCO Bank with $121 \%$ return on investment respectively from Banking Industry and Shree Cement from Cement Sector has given $285 \%$ returns to its investors. But another way of interpretation for our study is that, the portfolio return computed for the undervalued stocks has been higher compared to the portfolio return on overvalued stocks. Therefore this study brings evidence to the fact that, in order to ensure profit from equity investment, instead of forming the portfolio on basis of low Price-to-Earnings ratio, it better to form on the basis of PEG which is treated as a tool to find the undervalued stocks. Accordingly investment in such stocks is recommended for the construction of the portfolio. Hence 'PEG' is the best tool to make money in the long run especially in select equities when the 'PEG' is less than 1 . So using Price-Earnings ratio and dividing Price-Earnings ratio by expected growth rate 
suggest whether the stock in which an investor makes investment is undervalued or overvalued. As he should pay the price for earnings and also for growth in earnings, which a proxy for performance and growth is like live and grow for human beings. Hence PEG stands superior over P/E.

\begin{tabular}{|l|c|c|c|c|c|c|}
\hline \multicolumn{1}{|c|}{ Table : 3.9 STATEMENT SHOWING SECTOR WISE SUMMARY OF STOCK VALUATION } \\
\hline Sector & $\begin{array}{c}\text { Under } \\
\text { valued }\end{array}$ & $\begin{array}{c}\text { Over } \\
\text { valued }\end{array}$ & $\begin{array}{c}\text { Fair } \\
\text { valued }\end{array}$ & Total & $\begin{array}{c}\text { \% of } \\
\text { Under- } \\
\text { valued } \\
\text { stocks }\end{array}$ & $\begin{array}{c}\% \text { of } \\
\text { Overvalued } \\
\text { stocks }\end{array}$ \\
\hline Automobile & 02 & 03 & - & 05 & 40 & 60 \\
\hline Public Sector Banks & 05 & - & - & 05 & 100 & - \\
\hline Cement & 04 & 01 & - & 05 & 80 & 20 \\
\hline Power & 02 & 03 & - & 05 & 40 & 60 \\
\hline Pharmaceuticals & 01 & 04 & - & 05 & 80 & 20 \\
\hline Computer Software & 05 & - & - & 05 & - & 100 \\
\hline TOTAL & 19 & 11 & - & 30 & & \\
\hline
\end{tabular}

\section{SECTION: IV \\ FINDINGS, LIMITATIONS AND SUGGESTIONS}

\subsection{FINDINGS :}

Following are the major findings of our study.

1. The return on investment of undervalued stocks is ranging from $18 \%$ to $285 \%$ with average return of $154 \%$. While over valued stocks total return on investment is between $-24 \%$ to $181 \%$ with average return of $76 \%$.

2. The average return on investment of undervalued stocks is dominates with an aggregate return of $154 \%$ over average return on investment of overvalued stocks with an average return of $76 \%$. Therefore this an evidence to make investment on the basis of 'PEG'
3. The present study covers 30 scripts representing 6 sectors of Indian market. Out of these 19 stocks are undervalued and 11 stocks are overvalued and no stocks were fairly valued on PEG metric.

\subsection{LIMITATIONS:}

This paper suffers from the following limitations.

1. The analysis carried would have yielded good results if we were to compare this with other investing styles such as dividend yield investing, value investing, risk investing etc.

2. No fairly valued stocks have been found to form the portfolio consisting of 05 stocks each, one for undervalued and another for overvalued. 
3. Performance of the portfolio would have been read on returns, risk, liquidity and growth respectively. As far as this study is concerned, the performance of portfolio is read through the application of Return on investment. Higher Return on Investment better is the performance and vice-versa.

4. To ascertain the overvalued or undervalued stocks we have used PEG as an indicator. But we could also have used other indicators like Price-to- book ratio, dividend yield etc.

5. There is also sector limitation in Indian Context; there are large numbers of sector ranging from 1 to 25 . But for our study we have chosen only 6 sectors which may not be representative to entire Indian incorporations.

\subsection{SUGGESTIONS /LESSONS TO INVESTING CLASS:}

The following suggestions were offered to the investing class;

1. The low $P / E$ is not a perfect indicator of value stock. Hence PEG stocks be the good indicator for equity investment.

2. In forming the portfolio of undervalued stocks as per PEG a care should be taken to include different stocks of the different sectors. So that risk is diversified.

3. Undervalued stocks from sun rising industry be given performance in forming the portfolio.

4. PEG having higher Return on Equity is given performance. To speak specifically, ROE of the script should not be less than $15 \%$ is the general perspective of the investing class as Cost of Equity in most of the cases.

5. Undervalued stocks should have at least $10 \%$ of operating margin.

\section{REFERENCES :}

1. Rao, D.N. (2006), "Identifying Undervalued Stocks: A Case-study of Saudi Stock Market", Kings University, SSRN working paper series: 935084

2. Nicholson,S.F. (1968), "Price-Earnings Ratio in Relation to Investment Result", Financial Analysts Journal, 24(1): pp, 105-09.

3. Basu, S. (1975), "The Information Content of Price-Earnings Ratios”, FinancialManagement, 4(2): pp. 53-64.

4. Fuller, Huberts and Levinson (1993), "Returns to E/P Strategies, Higgeldy Piggeldy Growth, Analysts' Forecasts Errors, and Omitted Risk Factors", Journal of Portfolio Management, 1993(Winter): pp.13-24.

5. Dreman and Lufkin (1997), "Do Contrarian Strategies work within Industries? Journal of Investing, 6(3): pp. 7-29

6. Sharma (1984), "A Possible Explanation of the Small Firm Effect”, Journal of Finance, Vol. 36,No.4, September, pp.879-888.

7. Gillan(1990), "An Investigation into CAPM Anomalies in New Zealand: The small Firm and Price-Earnings Ratio Effects", Asia Pacific Journal of Management, Vol.7, December, pp.63-78

8. Obaidullah (1991), "The Price/Earnings Ratio Anomaly in Indian Stock Markets", Decision, Vol.18, July-September, pp. 183-190.

9. Campbell and Shiller (1988) and Shiller (2000), Irrational Exuberance of $P / E$, Princeton University Press

10. Tuli and Mittal (2001), "Determination of PriceEarnings Ratio" , Finance India, Vol. 15,No.4, December, pp.1235-1250.

11. Mohanty (2002), "Price-to-book value and Earnings-to-Price ratio, Princeton University Press.

12. Mangala and Mittal (2005), "Price earnings ratio in stock market", Journal of Finance, December. Pp. 55-62.

13. Dhankar and Kumar (2007), Determinations of Price-Earnings ratio, Decision, July September PP. 150-162 


\section{TERMS USED IN OUR STUDY :}

1. Price Earnings to Growth ratio:

The PEG ratio (Price/Earnings to Growth ratio) is a valuation metric for determining the relative trade-off between the price of a stock, the earnings generated per share (EPS), and the company's expected growth.

\section{Overvalued stock:}

A Stock is said to be overvalued when the ascertained value of $P E G$ is more than one. (PEG>1).

\section{Undervalued stock:}

If the calculated PEG is less than one for specific stock, such is termed as undervalued stock. $(P E G<1)$
4. Fairly valued stock:

A stock is said to be fairly valued only when the $P E G$ value of stock is equal to one $(P E G=1)$

5. Price-to-earnings ratio:

The P/E ratio (price-to-earnings ratio) of a stock (also called its "P/E", or simply "multiple") is a measure of the price paid for a share relative to the annual net income or profit earned by the firm per share.

6. Sustainable Growth Rate :

The sustainable growth rate is a measure of how much a firm can grow without borrowing more money. After the firm has passed this rate, it must borrow funds from another source to facilitate growth. 